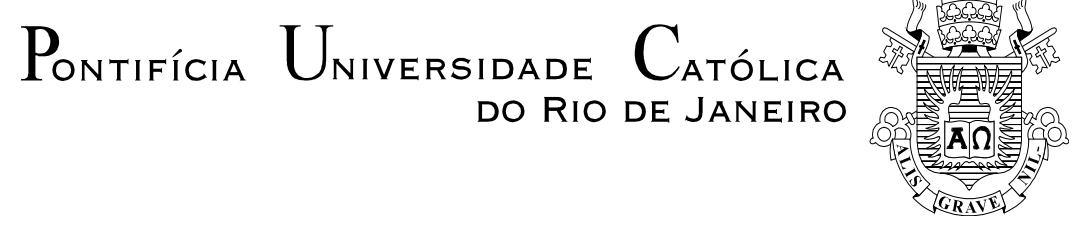

Victor Coutinho Lage

\author{
Interpretations of Brazil, \\ Contemporary (De)Formations
}

TESE DE DOUTORADO

Thesis presented to the Programa de Pós-Graduação em Relações Internacionais of the Instituto de Relações Internacionais, PUC-Rio as partial fulfillment of the requirements for the degree of Doutor em Relações Internacionais.

Advisor: Prof. Robert Brian James Walker

Volume I

Rio de Janeiro June 2016 


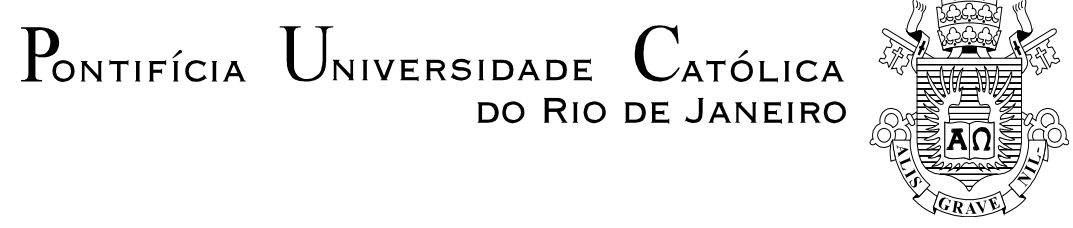

Victor Coutinho Lage

\section{Interpretations of Brazil, Contemporary (De)formations}

Thesis presented to the Programa de Pós-Graduação em Relações Internacionais of the Instituto de Relações Internacionais da PUC-Rio, as partial fulfillment of the requirements for the degree of Doutor.

Prof. Robert Brian James Walker Advisor Instituto de Relações Internacionais - PUC-Rio

Prof. Sergio Barreira de Faria Tavolaro Departamento de Sociologia - Universidade de Brasília

Prof. João Marcelo Ehlert Maia CPDOC - Fundação Getúlio Vargas

Prof. Paulo Luiz Moreaux Lavigne Esteves Instituto de Relações Internacionais - PUC-Rio

Prof. João Franklin Abelardo Pontes Nogueira Instituto de Relações Internacionais - PUC-Rio

Profa. Mônica Herz Coordinator of the Centro de Ciências Sociais da PUC-Rio

Rio de Janeiro, June 30th, 2016. 
All rights reserved

\section{Victor Coutinho Lage}

The author graduated in International Relations from Pontifícia Universidade Católica de Minas Gerais in 2008, he obtained the degree of Mestre at PUC-Rio in 2011

Bibliographical data

Lage, Victor Coutinho

Interpretations of Brazil, contemporary (de)formations / Victor Coutinho Lage ; advisor: Robert Brian James Walker. - 2016.

$2 \mathrm{v} . ; 30 \mathrm{~cm}$

Tese (doutorado)-Pontifícia Universidade Católica do Rio de Janeiro, Instituto de Relações Internacionais, 2016.

Inclui bibliografia

1. Relações internacionais - Teses. 2. Interpretações do Brasil. 3. Formação. 4. Modernidade. 5. Brasil moderno. 6. Periferia. I. Walker, Robert Brian James. II. Pontifícia Universidade Católica do Rio de Janeiro. Instituto de Relações Internacionais. III. Título.

CDD: 327 


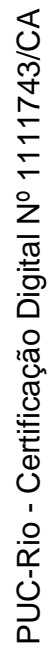

To/A Lucy, Verônica, Paulo, Milton, Pedro, Rob, Nick 


\section{Acknowledgments}

In a letter to Carlos Drummond de Andrade, Mário de Andrade said: "ultimately, everything is influence in this world. Each individual is an outcome of something. Now, there are good influences and bad influences. Besides that, one must distinguish what is influence from what is revelation coming from ourselves. Very often a book reveals to us a yet-unknown side of ourselves".

With that in mind, but considering that, ultimately, the precise distinction between "influence" and "revelation" is unknowable, I would like to acknowledge at least some people whose "good influence" I have been able to identify during the (de)formative moments of the $\mathrm{PhD}$.

Agradeço/I acknowledge:

À minha família, Lucy, Paulo, Verônica, Milton, Pedro, pelo apoio inestimável. Às pessoas que se tornaram fundamentais ao longo do tempo no Rio de Janeiro, em especial a Paulo Chamon, absolutamente leal; a Fernando Cyrino, inenarrável; a Fernando Maia, socrático; e a Amanda, incrível. Devo gratidão especial a Monica Herz, pela aposta em mim, pela amizade e pelo apoio acadêmico. Agradeço, ainda, a Manuela Viana, Numa Mazat, Natália Felix, entre outras pessoas amigas.

Nicholas Onuf and my advisor, Rob Walker, for the full support in each moment of the trajectory since my beginning in the master program. I will never be able to do full justice to all their encouragement during these (de)formative moments. I also acknowledge Onofre dos Santos Filho, Evando Nascimento, Mike Shapiro, Rafael Haddock-Lobo, and other professors that supported in different ways this enterprise.

I am deeply indebted to the professors I had during the $\mathrm{PhD}$ and to a decisive conversation with João Pontes Nogueira, who helped me in making the decision to stay at the Institute of International Relations for the $\mathrm{PhD}$. My special acknowledgment to Paulo Esteves, who, besides my professor, was part of my committee in the undergraduate and in the master, accepting now a third invitation. The topic of this dissertation comes in part from João's insistence with me back in 2009 on the necessity of taking into consideration the peripheral condition in the production of knowledge; it also comes in part from the comments made by Paulo 
and Eduardo Soares Neves Silva's (who remains a major reference to me) during the master's defense.

Às pessoas amigas do Instituto de Relações Internacionais, pela prazerosa convivência e pelo estimulante lugar de interpretação que construímos. Em especial, agradeço à Lia Gonzalez, cujo apoio fez de todo o processo algo menos complicado, e à Dayse, pela companhia desde cedo.

A alunas e alunos que me proveem a certeza acerca da trajetória que venho traçando.

My friends in Victoria, B.C. (Canada) where I spent unforgettable months as visiting student. Among them, no one was more important to me than Joanna. I would also like to mention Bob, sport partner, and Brian, who said crucial words in hard times. According to Paulo Prado, "in a trip to Paris, from the top of an atelier in 'Place the Clichy' - navel of the world - Oswald de Andrade discovered, dazzled, his own land. The return to his homeland confirmed... that surprising revelation that Brazil existed. This fact, already suspected by some people, opened his eyes to the radiant vision of a new, unexplored and mysterious world" (Paulo Prado, 1924). My return to Brazil from Victoria confirmed a surprising revelation: no Brazil exists.

À Coordenação de Aperfeiçoamento de Pessoal de Nível Superior (CAPES), pela bolsa de estudos nos primeiros 24 meses de doutorado, ao Fundo de Amparo à Pesquisa do Estado do Rio de Janeiro (FAPERJ), pela "Bolsa Nota 10 - Doutorado" nos 24 meses seguintes, e à Pontifícia Universidade Católica do Rio de Janeiro (PUC-Rio).

Muitas outras pessoas, algumas inomináveis, atravessam este escrito, embora este talvez jamais as atravesse. Augusto Boal once noted that "when one says 'I was influenced by some guy, or some writer', one is leaving aside so many other people that have also influenced oneself, that it is almost unfair to cite Shakespeare, to cite Cervantes,... to site all those people. Obviously they have influenced me powerfully. But social life, life observing people, chats with friends, have also influenced me powerfully... My friends have influenced me enormously... We talk about the influence coming from the books, but what about the influence coming from other people's experiences?". 


\section{Abstract}

Lage, Victor Coutinho; Walker, Robert Brian James. (Advisor). Interpretations of Brasil, Contemporary (De)formations. Rio de Janeiro, 2016. 624p. PhD Thesis - Instituto de Relações Internacionais, Pontifícia Universidade Católica do Rio de Janeiro.

The dissertation deals with writings from the XX century grouped under the notion of "interpretations of Brazil", focusing on their uses of the concept of "formation". I have identified five traces exposed in those uses: (1) the centrality of the nation; (2) the incompleteness of the transition from the colonial to the modern condition, marking a coexistence of the old and the new; (3) the internal inequality within the country; (4) the mobilization of external parameters in the definition of Brazil; and (5) the focus on the specificities of Brazilian formative process. These five traces are shared by all the texts selected; but, at the same time, they are expressed in different ways according to each text. Part I stresses the recurrence of the concept of "formation" in the "interpretations of Brazil" (chapter 2); after that, it lays out general lines of the perspective from which the uses of "formation" will be interpreted in the texts selected (chapter 3). Part II (chapters 4-12) is devoted to the interpretations of the texts, focusing on the uses of "formation" and those five traces previously mentioned. Part III begins with a controversy that took place mainly in the late 1980s and that is expressive of many aspects raised in Part II (chapter 13); then, it tackles three interpreters of Brazil that have advanced, in different ways, efforts similar to the one I will embrace myself in the last part of the text, that is, an alternative interpretation of the formation of contemporary Brazil from some kind of engagement with previous "interpretations of Brazil" (chapters 14-16). Finally, Part IV (chapter 17) builds on the previous discussion, in order to reflect upon, or "theorize" from, the five traces of "formation" in the "interpretations of Brazil".

\section{Keywords}

Interpretations of Brazil; formation; modernity; modern Brazil; periphery. 


\section{Resumo}

Lage, Victor Coutinho; Walker, Robert Brian James. (Orientador). Interpretações do Brasil, (De)formações Contemporâneas. Rio de Janeiro, 2016. 624p. Tese de Doutorado - Instituto de Relações Internacionais, Pontifícia Universidade Católica do Rio de Janeiro.

A tese lida com escritos do século $\mathrm{XX}$ agrupados pela designação "interpretações do Brasil", focando-se nos usos do conceito de "formação" nesses textos. Identifiquei cinco traços expostos nesses usos: (1) a centralidade da nação; (2) a incompletude da transição da condição colonial para a condição moderna; (3) a desigualdade interna no país; (4) a mobilização de parâmetros externos na definição do Brasil; e (5) o foco nas especificidades do processo formativo brasileiro. Esses cinco traços são comuns a todos os textos selecionados; no entanto, eles se expressam de maneiras diferentes de acordo com cada texto. A Parte I destaca a recorrência do conceito de "formação" nas "interpretações do Brasil" (capítulo 2); depois disso, expõe linhas gerais da perspectiva a partir da qual os usos de "formação" serão interpretados (capítulo 3). A Parte II (capítulos 4-12) se dedica à interpretação dos textos selecionados, com foco nos usos do conceito de "formação" e nos traços mencionados antes. A Parte III começa com uma controvérsia ocorrida principalmente no final dos anos 1980 e que se mostra expressiva de muitos aspectos levantadas na Parte II (capítulo 13); em seguida, abordo três intérpretes do Brasil que têm avançado, de formas diferentes, abordagens similares à que desenvolvo no final da tese; isto é, buscam uma interpretação alternativa da formação do Brasil contemporâneo (capítulos 14-16). Finalmente, a Parte IV parte da discussão precedente, a fim de refletir sobre os cinco traços de "formação" nas "interpretações do Brasil", "teorizando" a partir de certo "lugar".

\section{Palavras-chave}

Interpretações do Brasil; formação; modernidade; Brasil moderno; periferia. 


\section{Table of Contents}

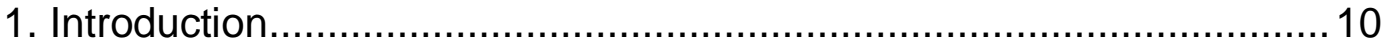

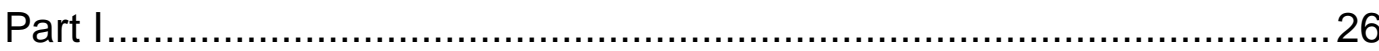

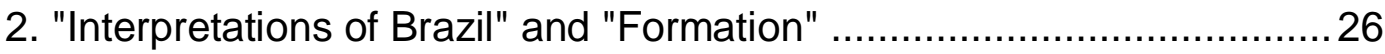

2.1(De)Forming "Brazil", Encountering "Modernity" ............................. 42

3. Aporetic Performances, Contemporary (De)Formations......................... 58

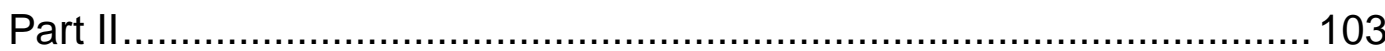

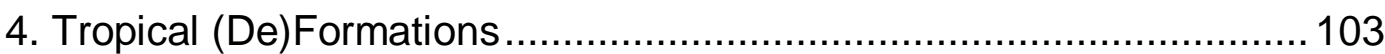

5. Aesthetic Formalization of Brazilian Formation ...............................139

6. Coexisting Forms Within A Specific Formation................................. 172

7.Capitalist (De)Formation: Minimal Decolonization,

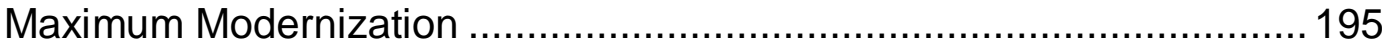

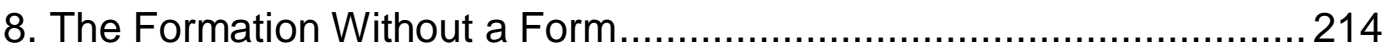

9.Episodic Formation of Underdevelopment.......................................233

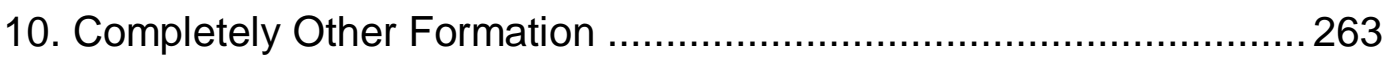

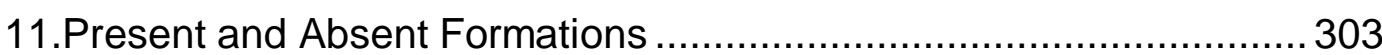

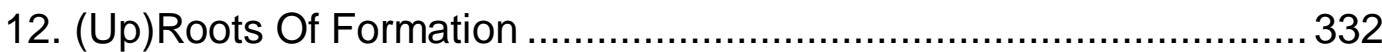

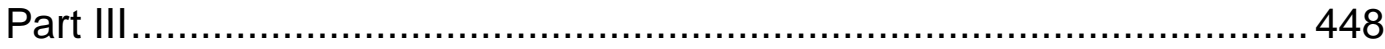

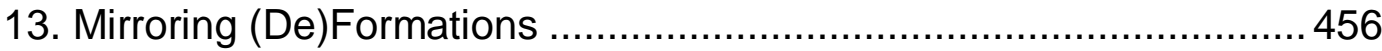

14. A Formative Process Between Present and Future ......................... 470

15. (Self-)Interpreting the Formation of Brazil(ians) .............................. 485

16. From a Dilemma to a Sociological Problem of Formation..................511

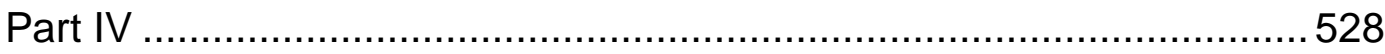

17. Conclusion; Or, Aporetic Performances,

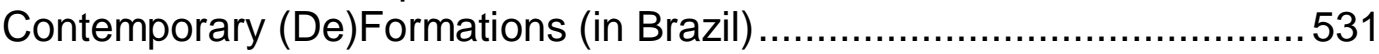

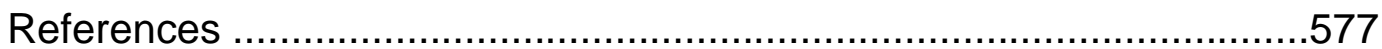

